\title{
Seed Health Evaluation of Different Varieties of Indian Bean by Incubation Method (Roll Paper Towel)
}

\author{
Kiran Pradhan* and N. Lakpale \\ Department of Plant Pathology, College of Agriculture, Indira Gandhi Krishi \\ Vishwavidyalaya, Raipur, Chhattisgarh.492012, India \\ *Corresponding author
}

\section{A B S T R A C T}

\begin{tabular}{|l|}
\hline Key w o r d s \\
$\begin{array}{l}\text { Indian bean, Roll } \\
\text { paper towel, Seed } \\
\text { borne mycoflora }\end{array}$ \\
\hline Article Info \\
\hline $\begin{array}{l}\text { Accepted: } \\
\text { 25 April } 2020 \\
\text { Available Online: } \\
10 \text { May } 2020\end{array}$ \\
\hline
\end{tabular}

Five varieties of Indian bean and one local variety were taken in the investigation to assess the seed health evaluation by roll paper towel method. The seeds were placed on moist paper towel at equidistance and covered with another moist paper towel and rolled carefully without disturbing the already arranged seeds. Tie the towel with rubber band at both the ends. Incubate it for four to five days at room temperature. Examine normal and abnormal seedlings, cause of abnormalities, failure in germination and ungerminated seeds by naked eye and presence of mycoflora by stereo-binocular microscope. Maximum frequency of mycoflora were recorded from local variety seed lot (99.98\%) and IS- 12 variety showed minimum frequency of mycoflora (92.84\%).

\section{Introduction}

Indian bean or field bean (Lablab purpureus L.) is predominantly self-fertilizing and its chromosome number is $2 n=22$. It is short lived creeping perennial but used as an annual legume. Indian bean is one of the most ancient crops among cultivated plants. Indian bean locally known as 'Sem' belongs to the family Fabaceae subfamily Papilionaceae (Dhaliwal, 2008). Other names for this legume are dolichos bean, lablab bean, hyacinth bean, Egyptian bean, Sembean, Lubia bean (Sudan) and Egyptian kidney bean
(Purseglove,1968). The species is extremely diverse and taxonomically three sub-species are recognized, mainly based on differentiating characteristics of pods and seeds.

Indian bean is presently grown throughout the tropical regions in Asia, Africa and America. In Chhattisgarh, beans occupies an area of 7828 hectare with the production of 94415 million tonne with an average productivity 12 milliontonne/hectare during the year 2017-18 (Krishi Darshika, 2019). In India, the important growing states are Uttar Pradesh, 
Madhya Pradesh, Haryana, West Bengal, Tamil Nadu, Telangana, Andhra Pradesh, Karnataka and Maharashtra (Dhaliwal, 2008). In North East India, its tender pod is a popular vegetable and it is mostly grown as a backyard crop and occasionally sold on limited scale for local market during winter (Sarma et al., 2010). A large number of indigenous land races are found scattered all over North East India, distinguished primarily on the basis of pod morphology and pod coloration. The consumer preference varies with pod size, shape, colour, softness and aroma.

Indian bean is a multipurpose crop grown for pulse, vegetable for human consumption and also used as forage for animals (Murphy and Colucci, 1999). Compared to many other vegetables, Indian bean pods have longer shelf life (Sarma et al., 2010). In addition to food and forage crop, Indian bean bean is often grown as a weed suppressor and as a cover crop to avoid soil erosion or as a green manure crop. Indian bean is a versatile crop which is can be cultivated in a range of climates and soil types (Pengelly and Maass, 2001). It is a cool season crop that responds to photoperiod. The seeds of Indian bean have a greater nutritive value having $3.8 \mathrm{~g} / 100 \mathrm{~g}$ of protein, $6.7 \mathrm{~g} / 100 \mathrm{~g}$ of carbohydrate, $0.7 \mathrm{~g} / 100 \mathrm{~g}$ of fat, $1.8 \mathrm{~g} / 100 \mathrm{~g}$ of fibre, oxalic acid 1 $\mathrm{mg} / 100 \mathrm{~g}$ and vitamin A- $312 \mathrm{IU}$.

Diseases are the major constraint in economic crop production as they inflict heavy losses. Like other crops, Indian bean is also attacked by many diseases during seed germination to seed production and maturity. The crop is affected by many fungal diseases viz., anthracnose (Colletotrichum lindemuthianllm), rust (Uromyces appendiculatus), powdery mildew (Erysiphe polygoni), ashy blight and charcoal rot (Macrophomina phaseolina), leaf spot (A. tenuissima), bacterial disease viz., bacterial blight (Xanthomonas phaseoli) and viral diseases viz., bean common mosaic (BCM) and bean yellow mosaic (BYM) (Bose et al., 2001).

The roll paper towels containing seeds were incubated in dark at suitable temperature for fixed period of time. The seeds were examined after incubation for the presence of micro-organisms and germination. This method is used for the detection of various seed borne mycoflora of seeds of Indian bean varieties.

\section{Materials and Methods}

The seeds were placed on moist paper towel (25-50) at equidistance and covered with another moist paper towel and rolled carefully without disturbing the already arranged seeds. Tie the towel with rubber band at both the ends. To avoid water loss, used polythene or wax coated paper wrapping the rolled paper towels containing seeds. Incubate it for four to five days at room temperature. Examine normal and abnormal seedlings, cause of abnormalities, failure in germination and ungerminated seeds by naked eye and presence of mycoflora by stereo-binocular microscope. The observations were recorded for-

Normal seedlings show the potential for continued development into satisfactory plants when grown in good quality soil and under favorable conditions of temperature, light and moisture.

\section{Categories}

Intact seedlings-seedlings with all their essential structures well developed, complete in proportion and healthy.

Seedlings with slight defects-seedlings showing slight defects of their essential 
structures provided they show a satisfactory and balanced development comparable to that of intact seedlings of the same test.

Seedlings with secondary infection seedlings as described above but have been affected by fungi or bacteria from sources other than the parent seed.

Abnormal seedlings- do not show the potential to develop into a normal plant when grown in good quality soil and under favorable condition of moisture, temperature and light.

\section{Categories}

Damaged - seedlings with any of the essential structures missing or badly and irreparably damaged that balance development cannot be expected.

Deformed or unbalanced - seedlings with weak development or physiological disturbances or in which essential structures are deformed or out in proportion.

Decayed - seedlings with any of their essential structures so diseased or decayed as a result of primary infection that normal development is prevented.

Ungerminated seeds-did not germinate at the end of the test period.

\section{Categories}

Hard seeds - seeds which have not absorbed water thus remain. Hard after the end of the test period.

Fresh seeds - seeds able to imbibe water but which failed to germinate under the condition of the germination test remains clean and firm and have the potential to develop into a normal seedling.
Dead seeds - seeds at the end of the test period are neither hard nor fresh, failed to proof a seedling; usually soft, discolored, frequently moldy.

Others- empty, embryo less seeds, insect damaged seeds.

\section{Results and Discussion}

Seed lot of six varieties of Indian bean were examined for associated seed borne mycoflora in varying frequencies with normal seedling, abnormal seedling and ungerminated seeds by roll paper towel method. It was observed that presence of mycoflora may be the cause of abnormalities and failure in germination. In this method, mycoflora were found associated with seeds and seedling of Indian bean varieties. Maximum frequency of mycoflora were recorded from local variety seed lot $(99.98 \%)$ and mycoflora detected were Aspergillus flavus (36.84\%), Curvularia lunata (26.31\%), Alternaria alternata (21.05\%) and Aspergillus fumigatus (15.78\%) and germination percentage recorded (90\%) followed by frequency of mycoflora in IS-2 (98.25), IS-29 (96.99\%), IS-1 (96.06\%), IS-96 $(95.22 \%)$ and IS-12 (92.79\%) and germination percentage recorded in all these Indian bean varieties were 70, 90, 90, 80 and 60 , respectively.

In seeds of IS-2 variety mycoflora were detected as Alternaria alternata (38.26\%), Fusarium sp. (33.33\%) and Aspergillus flavus $(26.66 \%)$. In IS-29 variety associated mycoflora detected as Alternaria alternata (41.62\%), Fusarium sp. (30.37\%) and Aspergillus fumigatus (25\%). Mycoflora detected in IS-1 as Aspergillus fumigatus (42.46\%), Aspergillus flavus (30.33\%) and Fusarium sp. (23.27\%). Seed lot of IS-12 variety mycoflora was detected as Aspergillus flavus (42.45\%), Alternaria alternata (26.27\%) and Fusarium sp. (24.12\%). IS- 96 
variety showed minimum frequency of mycoflora $(85.22 \%)$ includes Aspergillus terreus (33.33\%), Alternaria alternate
(28.57\%), Fusarium sp. (19.04\%) and Aspergillus fumigatus (14.28\%).

Table.1 Detection of mycoflora associated with seeds of Indian bean varieties by roll paper towel method

\begin{tabular}{|c|c|c|c|c|c|c|c|c|c|}
\hline \multirow[t]{2}{*}{ S.No } & \multirow[t]{2}{*}{ Varieties } & \multirow{2}{*}{$\begin{array}{c}\text { Germination } \\
(\%)\end{array}$} & \multicolumn{6}{|c|}{ Frequency of mycoflora associated $(\%)$} & \multirow{2}{*}{$\begin{array}{c}\text { Total } \\
\text { frequency } \\
(\%)\end{array}$} \\
\hline & & & षं & $\dot{4} \widetilde{\Xi}$ & $\dot{\square}$ & 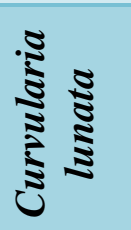 & 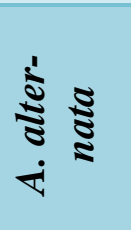 & 妾 & \\
\hline 1 & IS - 1 & 90 & 30.33 & 42.46 & - & - & - & 23.27 & 96.06 \\
\hline 2 & IS - 2 & 70 & 26.66 & - & - & - & 38.26 & 33.33 & 98.25 \\
\hline 3 & IS - 12 & 60 & 42.45 & - & - & - & 26.27 & 24.12 & 92.84 \\
\hline 4 & IS - 29 & 90 & - & 25.00 & - & - & 41.62 & 30.37 & 96.99 \\
\hline 5 & IS - 96 & 80 & - & 14.28 & 33.33 & - & 28.57 & 19.04 & 95.22 \\
\hline 6 & $\begin{array}{l}\text { Local } \\
\text { variety }\end{array}$ & 90 & 36.84 & 15.78 & - & 26.31 & 21.05 & - & 99.98 \\
\hline \multicolumn{2}{|c|}{ Total mvcoflora } & & 136.28 & 97.52 & 33.33 & 26.31 & 157.51 & 130.13 & \\
\hline
\end{tabular}
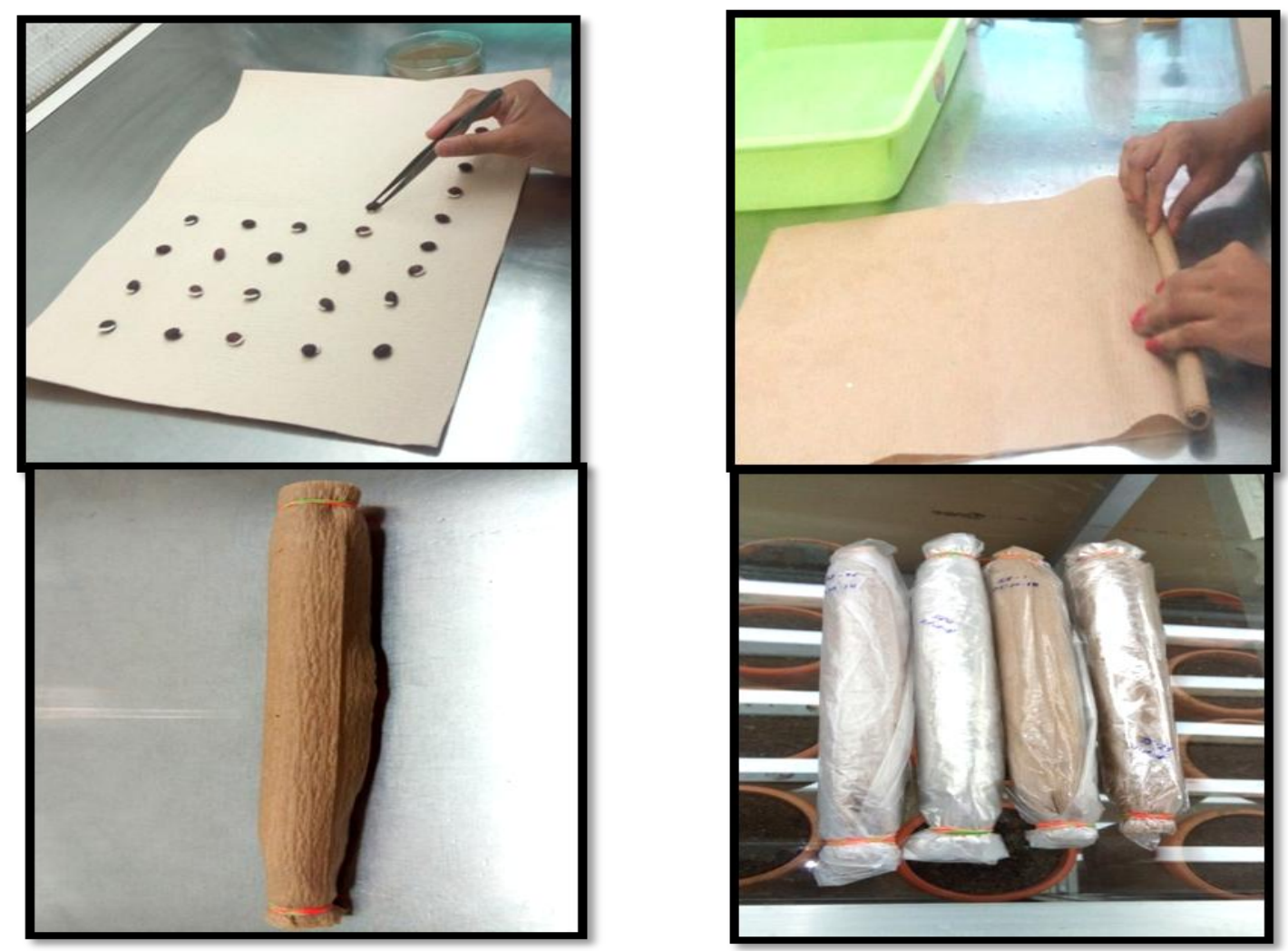

Plate.1 Roll paper towel method 
Fig.1 Detection of mycoflora associated with seeds of Indianbean varieties by roll paper towel method

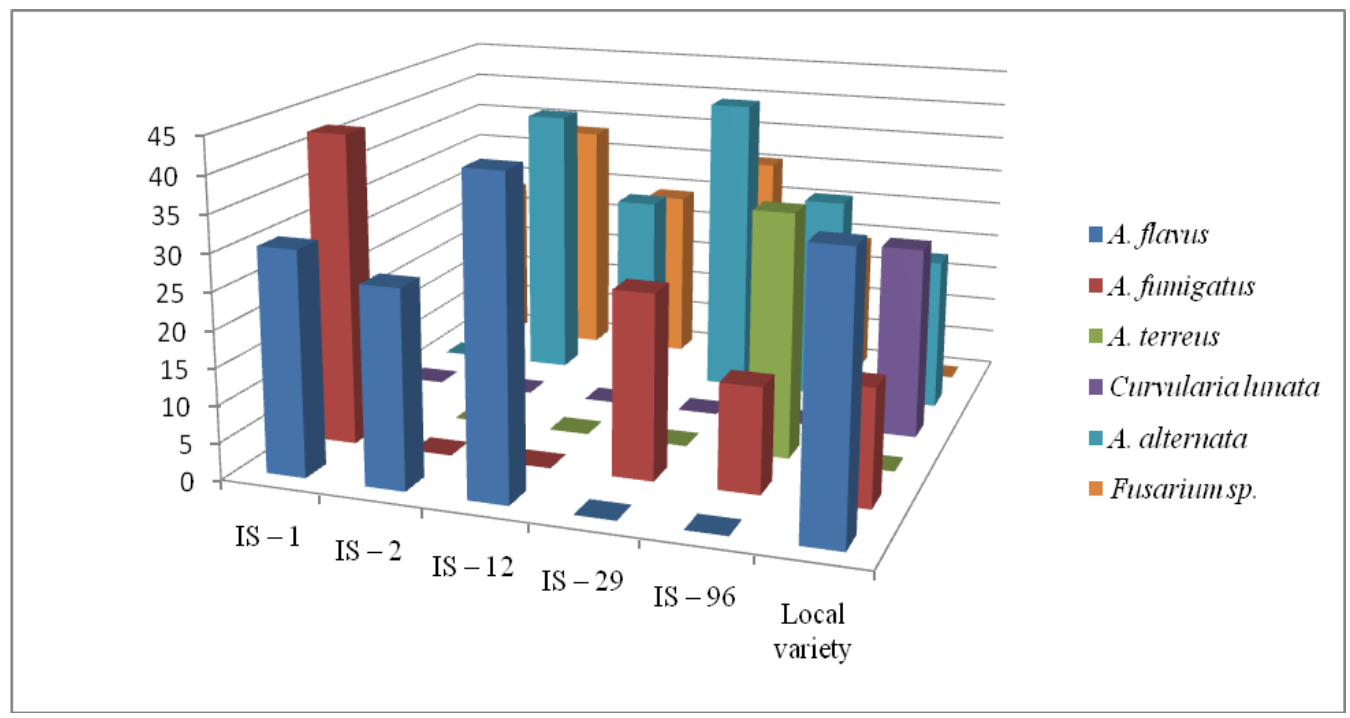

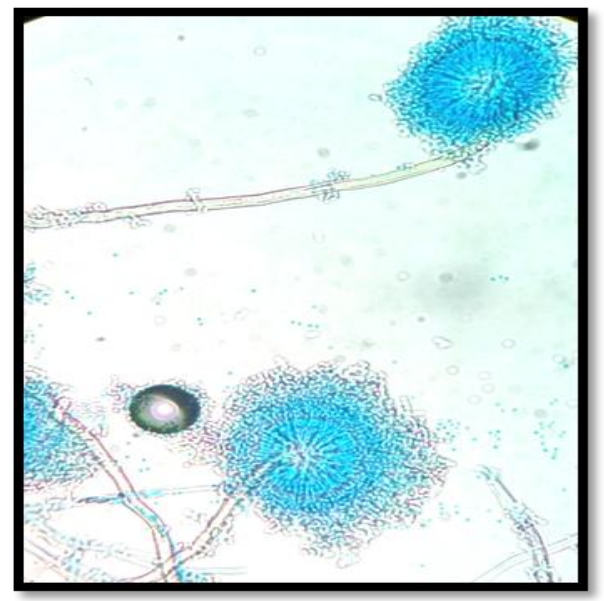

A. flavus

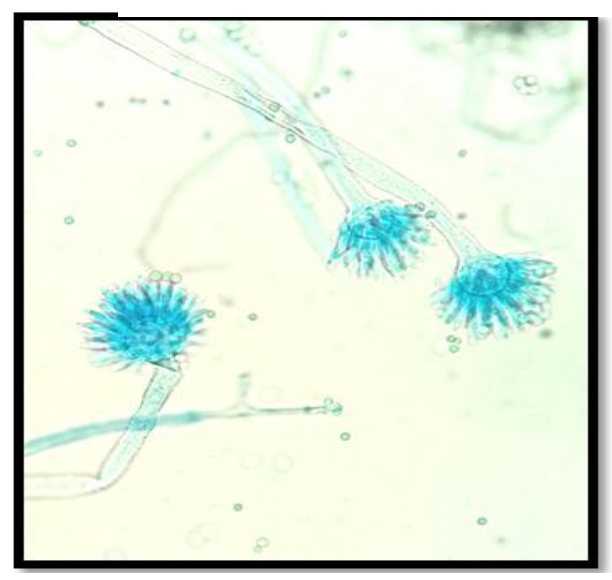

A. terreus

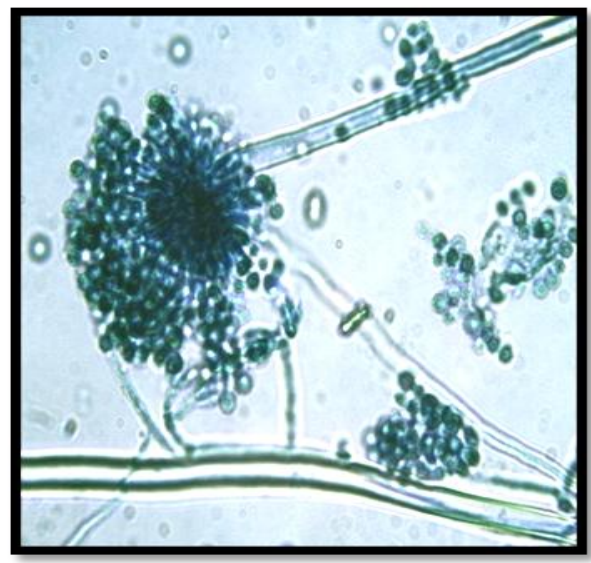

A. fumigatus

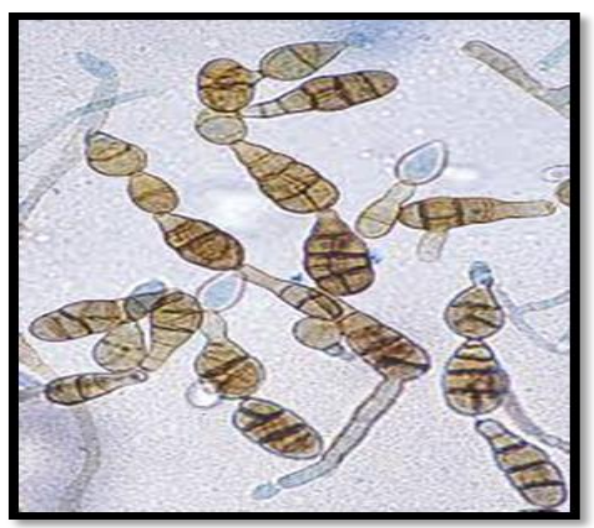

Alternaria alternata 


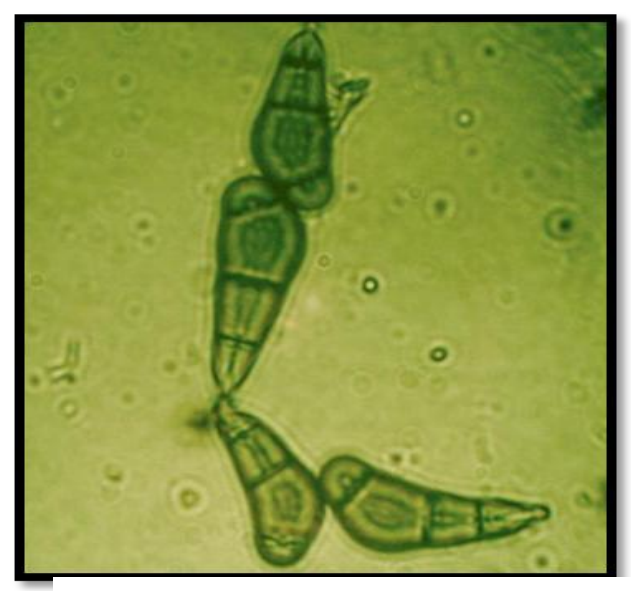

Curvularia lunata

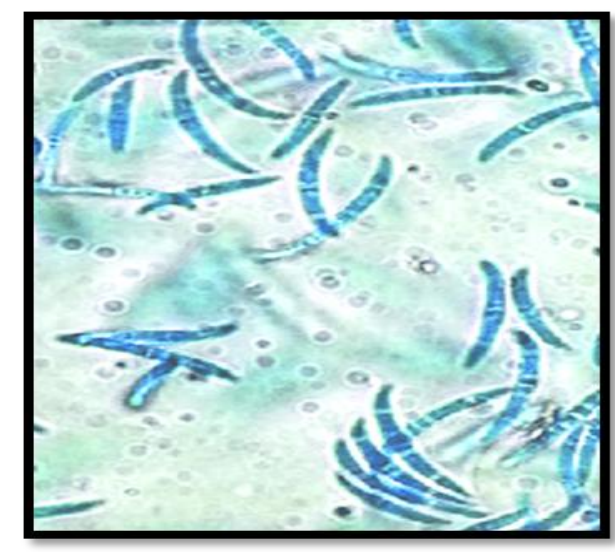

Fusarium sp.
Relative abundance Alternaria alternate $(157.51 \%)$ was maximum followed by Aspergillus flavus (136.28\%) and Fusarium sp. (130.13\%).

Commonly occurring seed borne mycoflora found associated with seeds of chickpea and pigeonpea were reported by Singh et al., (2014) and seed borne mycoflora of pigeonpea by Pradhan (2014) were in conformity with the findings of present study in which most common fungi in varying frequencies and their impact on germination were recorded.

Pradhan (2014) detected mycoflora in pigeonpea by roll towel method namely Aspergillus flavus, A. niger, A. fumigatus, A. sp., Penicillium sp., Mucor sp., and Fusarium udum. Singh et al., (2014) observed that mycoflora in wheat, paddy, pigeonpea and chickpea and Kesharwani (2018) in different pea varieties and mycoflora detected were Aspergillus flavus, Aspergillus niger, Aspergillus fumigatus, Trichoderma sp., Alternaria sp., Curvularia sp., Chaetomium sp. and Rhizopussp.by rolled paper towel method. Findings of present investigation are in agreement of finding of earlier researchers.

\section{References}

Bose T.K., Kabir J., Das P., Joy P.P. 2001. Tropical horticulture. Volume 2.Tropical horticulture. Volume 2, 771 pp.

Chaudhari, A.K., Sharma, H., Jehani, M. and Sharma, J.K. 2016. Seed Mycoflora Associated with Pigeonpea (Cajanus cajan (L.) Millsp.), their Significance and the Management. Journal of pure and applied microbiology. 11(1): 567575.

Dhaliwal, G.S. 2008. Dolichos bean. Handbook of Vegetable Crops, Kalyani Publisher, New Delhi, pp. 67.

Kesharwani, A. 2018 studies on Seed health evaluation different varieties of pea (Pisum sativum L.) M. Sc. (Ag.) Thesis submitted to Indira Gandhi Krishi Vishwavidyalaya, Raipur (C.G.).

KrishiDarshika, 2019. Indira Gandhi Krishi Vishwavidyalaya, Raipur C.G. pp: 6.

Murphy, A.M. and Colucci, P.E. (1999) A Tropical Forage Solution to Poor Quality Ruminant Diets: A Review of Lablab purpureus. Livestock Research for Rural Development, 11, 96-113.

Nagerabi, S.A.F., Shafie, A.E. and Abdalla, A.H. 2000. Composition of mycoflora 
and aflatoxins in pea seeds from the Sudan. Kuwait journal of science and engineering. 27(1): 109-122.

Pengelly B.C. and Maass B.L. 2001 Lablab purpureus L. diversity, Potential use and determination of a core collection of this multi purpose tropical legume. Genet Resour crop E. vol 48: 261- 272

Pradhan, A. 2014. Studies on seed mycoflora associated with pigeonpea (Cajanus cajan (L.) Mill sp). M. Sc. (Ag.) Thesis submitted to Indira Gandhi Krishi Vishwavidyalaya, Raipur (C.G.).

Purseglove J. W. 1968. Tropical Crops, Dicotyledons. Vol L London, UK; Longmans Greens and Company Ltd. pp 273-276.

Sarma B., Sarma A., Handique G.K. and Handique A.K. 2010. Evaluation of country bean (dolichos lablab) land races of north east India for nutritive values and characterization through seed protein profiling. Legume Res., 33 (3): $184-189$.

Singh, S., Sinha, A. and Mishra J. 2014. Evaluation of different treatment on the occurrences of seed borne fungi of mungbean Vigna radiate (L.) Wilczek seed. Academic Journals. 9(44): 33003304.

Singh, S., Sinha, A., Kumar, S. and Yadav, S.M. 2014. Determination of seed germination percent and effect of Trichoderma harzianum rafai on fresh and stored seed by different methods. International quarterly journal of environmental sciences. 4: 181-185.

\section{How to cite this article:}

Kiran Pradhan and Lakpale, N. 2020. Seed Health Evaluation of Different Varieties of Indian Bean by Incubation Method (Roll Paper Towel). Int.J.Curr.Microbiol.App.Sci. 9(05): 35103516. doi: https://doi.org/10.20546/ijcmas.2020.905.417 